\title{
All-offspring dispersal in a tropical mammal with resource defense polygyny
}

\author{
Dina K. N. Dechmann • Elisabeth K. V. Kalko • \\ Gerald Kerth
}

Received: 1 September 2006 /Revised: 9 January 2007 / Accepted: 10 January 2007 / Published online: 30 January 2007

(C) Springer-Verlag 2007

\begin{abstract}
In polygynous mammals, males are usually responsible for gene flow while females are predominantly philopatric. However, there is evidence that in a few mammalian species female offspring may disperse to avoid breeding with their father when male tenure exceeds female age at maturity. We investigated offspring dispersal and local population structure in the Neotropical bat Lophostoma silvicolum. The mating system of this species is resource defense polygyny, with the resource being active termite nests, excavated by single males, which are then joined by females. We combined field observations of 14 harems during 3 years and data about the genetic structure
\end{abstract}

Communicated by G. Wilkinson

D. K. N. Dechmann • G. Kerth

Zoologisches Institut, Universität Zürich,

Winterthurerstrasse 190,

8057 Zürich, Switzerland

D. K. N. Dechmann • E. K. V. Kalko

Experimental Ecology, University of Ulm,

Albert-Einstein Allee 11,

89069 Ulm, Germany

E. K. V. Kalko

Smithsonian Tropical Research Institute,

P.O. Box 2072, Balboa, Panama

G. Kerth

Department of Ecology and Evolution,

University of Lausanne, Biophore,

1015 Lausanne, Switzerland

D. K. N. Dechmann $(\bowtie)$

Institute of Anatomy - Division of Neuroanatomy,

University Zürich-Irchel,

Winterthurerstrasse 190,

8057 Zürich, Switzerland

e-mail: d.dechmann@anatom.unizh.ch within and between these groups, calculated with one mitochondrial locus and nine nuclear microsatellite loci. The results show that both male and female offspring disperse before maturity. In addition, we estimated life span of excavated termite nests and the duration they were occupied by the same male. Our findings suggest that long male tenure of up to 30 months is indeed a likely cause for the observed dispersal by female offspring that can reach maturity at a low age of 6 months. We suggest that dispersal by offspring of both sexes may occur quite frequently in polygynous tropical bats and thus generally may be more common in mammals than previously assumed.

Keywords Male tenure $\cdot$ Roost making $\cdot$ Population structure $\cdot$ Lophostoma silvicolum $\cdot$ Mating system

\section{Introduction}

Mating systems strongly influence dispersal patterns and thus mammalian population structure (Greenwood 1980; Dobson 1982; Perrin and Mazalov 1999). The most common mammalian mating system is polygyny, where a minority of males monopolize one or several females and mate with them, while most males gain little or no access to females (Clutton-Brock 1989b; Shuster and Wade 2003). Male mammals as the main dispersers are usually responsible for gene flow (Greenwood 1980; Dobson 1982). It is less common for female mammals or both sexes to disperse whereas in birds, females predominantly disperse (Greenwood 1980; Clutton-Brock 1989a; Clarke et al. 1997; but see Williams and Rabenold 2005). At least three major influences on sex-specific dispersal behavior have been suggested: (1) in polygynous species with little or no paternal care the cost of inbreeding is high for females but 
low for males (Clutton-Brock 1989a); (2) costs of dispersal are likely to be higher for females than for males (CluttonBrock 1989a; but see Hammond et al. 2006); and (3) the degree of cooperation (motivation to stay) vs competition for resources (motivation to disperse) among related females in a group (Greenwood 1980; Clutton-Brock 1989a,b). Most models predict that in polygynous mammals, high mate competition for females leads to male dispersal, whereas the most likely cause for females dispersal is to avoid inbreeding with the father when male tenure exceeds female age at first breeding although other reasons or a combination of them are also possible and are often disputed (Clobert et al. 2001).

In bats, most known mating associations are composed of a single male and several females (McCracken and Wilkinson 2000). Such groups are usually called harems, although the female composition is often unstable or only temporarily stable (Storz et al. 2000; Dechmann et al. 2005). This is also known from other polygynous mammals such as ungulates (e.g., Ruckstuhl and Neuhaus 2000). However, knowledge about bat mating systems is far from complete. In fact, the mating system was known in only $6.9 \%$ of the more than 1,000 species described by the year 2000 (McCracken and Wilkinson 2000). Moreover, bat mating systems have often been described on the basis of observations alone, which may yield misleading conclusions and must be complemented by genetic data (Heckel et al. 1999; Rossiter et al. 2000b; Kerth and Morf 2004; Rossiter et al. 2005). Another limitation to our knowledge of bat mating systems results from the fact that most studies on bat population genetics have focused on maternity colonies of species from the temperate zone. Such colonies occur only during part of the year and are not typically where matings take place. Few studies link data on bat mating systems to patterns shaping genetic population structure, such as offspring dispersal (Rossiter et al. 2000a; Burland and Worthington-Wilmer 2001; Petit et al. 2001; Kerth et al. 2002a, 2003). Finally, gene flow in bats has most often been investigated at a large geographical scale (Burland and Worthington-Wilmer 2001) where the effect of mating systems may not be detectable (Rossiter et al. 2000a; Castella et al. 2001; Petit et al. 2001; but see Burland et al. 2001; Kerth et al. 2002b).

In accordance with the general mammalian pattern (Greenwood 1980), females of most group-living bats, including some harem-forming species and all temperate zone species, are strongly philopatric (Burland et al. 1999, 2001; Kerth et al. 2000; Castella et al. 2001; Petit et al. 2001; Rossiter et al. 2002). In contrast, males of most species studied to date leave the natal colony and live solitarily or in groups of males. Or, if they are philopatric, they usually do not mate with the females in their natal colony (Burland et al. 1999; Worthington-Wilmer et al.
1999; Kerth et al. 2000; Castella et al. 2001; Petit et al. 2001; Kerth and Morf 2004). Both, genetic and behavioral evidence from the few studies on mating systems in tropical bats suggest that in some cases, offspring of both sexes disperse even though most of these studies did not specifically address this issue (McCracken and Bradbury 1981; Storz et al. 2001; Heckel and von Helversen 2003; but see Wilkinson 1985).

We investigated dispersal behavior in terms of the proportion of offspring leaving the natal colony and the genetic structure of a population of Lophostoma silvicolum. This bat lives year-round in small groups of one adult male with a maximum of 11 females and the most recent cohort of immature offspring. The majority of the males are solitary or live in bachelor groups (Dechmann et al. 2005). Solitary males excavate active termite nets and use the resulting cavity as a day roost. These roosts provide a warm and stable microclimate, which is probably advantageous for reproductive females and their offspring (Dechmann et al. 2004, 2005). Cavity-owning males are larger than average males and in better physical condition. They sire at least $50 \%$ of the offspring of the females who join them. The mating system is a resource defense polygyny and the females, who sometimes switch roosts between reproductive periods, may join a male and give birth in his roost, to an offspring sired by another male (Dechmann et al. 2005). Consequently, not all offspring in a male's roost are related to him although most are probably sired by other harem males, which the mother was roosting with at the time of conception. The resulting relatively high reproductive success probably justifies the investment of time and energy required for excavation and maintenance of the roosts (Dechmann et al. 2005).

We assessed gene flow between groups of $L$. silvicolum using sequence data from the mitochondrial d-loop and nine polymorphic nuclear microsatellite loci. We sampled social groups year-round, recording the number and sex of adults and offspring. In addition, we compared numbers of males we caught in roosts with those caught outside the roost, while foraging, to be sure that the skewed sex ratio in social groups (Dechmann et al. 2005) was due to the mating system and not increased male mortality. We predicted that male offspring would disperse to gain access to females as there is always only one adult male present in each harem (Dechmann et al. 2005). Regarding the females we tested two hypotheses: (1) Females are philopatric. In this case, we expected matrilineal group structure and low diversity of mitochondrial DNA in female groups. (2) Females leave the natal colony. In this case, dominant male tenure should exceed female age at first breeding (Clutton-Brock 1989a). Groups should then be composed of unrelated females, and mitochondrial as well as nuclear DNA should have high diversity within groups and not be differentiated between 
groups (if females disperse individually and not together in cohorts). Finally, we measured longevity of excavated termite nests and maximum time of male roost-occupancy to estimate male tenure.

\section{Methods}

\section{Study site}

Most data were collected on the 1,560 ha Barro Colorado Island $\left(\mathrm{BCI}, 9^{\circ} 10^{\prime} \mathrm{N}, 79^{\circ} 51^{\prime} \mathrm{W}\right)$, at a field station of the Smithsonian Tropical Research Institute at the center of the Barro Colorado Natural Monument (BCNM). Bats were also caught from two roosts on mainland peninsulas in the BCNM. Finally, we collected DNA samples from three roosting groups in the 22,000 ha Soberania National Park (Soberania, $9^{\circ} 07^{\prime} \mathrm{N}, 79^{\circ} 42^{\prime} \mathrm{W}$ ), which stretches along the mainland border of the Panama Canal, $15 \mathrm{~km}$ northeast of BCI.

\section{Study organism}

L. silvicolum is a medium-sized (males: $32 \mathrm{~g}$, females: $30 \mathrm{~g}$; Dechmann et al. 2005), gleaning, insectivorous bat occurring in lowland rainforests from Southern Mexico to Northern Brazil (Reid 1997). One out of about 50 individuals we caught in nets was a L. silvicolum; thus, it is a fairly common species at our study site (in comparison: only one Desmodus rotundus was caught in 500 individuals; see also Kalko et al. (1996). The species has small home ranges of 20.7 ha (Bockholdt 1998; Kalko et al. 1999) and uses a sitand-wait foraging-strategy, detecting prey by passive listening (Kalko et al. 1999). It uses termite nests as day and night roosts exclusively (Kalko et al. 2006) but does not feed on the termites (Kalko et al. 2006; unpublished data).

Capture and marking of individuals

We captured L. silvicolum between March 2000 and June 2003 , in mistnets along forest trails, or directly from roosts. In termite nests, we caught bats when pups were present and sometimes also immediately after we found a roost. Between one and three capture attempts were made per roost, usually not in the same reproductive season. The methods used to find nests as well as to track and catch bats follow Dechmann et al. (2005). We determined the location of each roost using a GPS receiver (Garmin 12; Garmin) with an accuracy of $2-10 \mathrm{~m}$ and evaluated the ratios of males and females caught in roosts and mistnets with $\chi^{2}$ tests (SPSS 11, SPSS, Chicago, USA).

We obtained DNA by cutting a small piece from the patagial membrane tissue of all individuals with a 3-mm sterile biopsy punch (Stiefel, Germany). The resulting hole healed completely within 3 weeks (Dina Dechmann; personal observation). Tissue was stored in 95\% ethanol until DNA extraction in the lab. Finally, we marked bats with passive, subcutaneous transponders (PIT-tags, EuroID. Weilerswist, Germany). Each transponder carries an individual code that can be recorded with a hand-held reader or with a self-made antenna attached to an automatic reader (Kerth and König 1996; Dechmann et al. 2005). We did not mark pups younger than 3 weeks or bats not caught on BCI.

DNA analysis

We extracted DNA from tissue samples using a saltchloroform method (Müllenbach et al. 1989). All individuals were originally screened with a panel of 10 polymorphic microsatellite loci. Nine loci were specific to L. silvicolum, while one (locus AJA123) was isolated from Artibeus jamaicensis (Ortega et al. 2002). Primers, reaction conditions, and loci characteristics were described by Dechmann et al. (2002, 2005).

Mitochondrial DNA was investigated by sequencing $340 \mathrm{bp}$ of the d-loop region with one primer pair (primer E: CCT GAA GTA GGA ACC AGA TG (Wilkinson and Chapman 1991); and primer $\mathrm{P}^{*}$ : CCC CAC CAT CAA CAC CCA AAG CTG A (Wilkinson et al. 1997)). Before analysis, 20-50 ng of mitochondrial DNA was amplified in a PCR with $1 \times$ Amplimix buffer (Microsynth; including $1.5 \mathrm{mM} \mathrm{MgCl}_{2}$, and $\left.0.2 \mathrm{mM} \mathrm{dNTP} \operatorname{mix}\right), 0.5 \mathrm{U}$ taq polymerase (Pharmacia), and $0.24 \mu \mathrm{M}$ of each primer. Total reaction volume was $25.0 \mu \mathrm{l}$. All ingredients are given in final concentrations. A PTC-200 thermocycler (MJ Research) was then programmed to perform 35 cycles of $94^{\circ} \mathrm{C} / 30 \mathrm{~s}, 58^{\circ} \mathrm{C} / 45 \mathrm{~s}$, and $72^{\circ} \mathrm{C} / 60 \mathrm{~s}$ after an initial $94^{\circ} \mathrm{C} / 4 \mathrm{~min}$ step and followed by $72^{\circ} \mathrm{C} / 20 \mathrm{~min}$. We tested $5 \mu \mathrm{l}$ of the PCR product on a $1.4 \%$ agarose gel $(1 \mathrm{~h}: 4.5 \mathrm{~V} / \mathrm{cm})$ stained with ethidium bromide. PCR products were purified using a Qiagen purification kit. After we had confirmed the reliability of our detection of variable sites by sequencing 50 animals in both directions, we sequenced all other samples in only one direction (primer $\mathrm{P}^{*}$ ) using the ABI prism dRhodamine terminator cycle sequencing ready reaction kit (Applied Biosystems). DNA sequences were then run on an ABI Prism 310 capillary sequencer. Data were exported with Sequencing analysis 3.4 (Applied Biosystems) and afterwards aligned and edited with Sequencher 4.1 (Gene Codes).

Structure within and between harems

We tested the 10 nuclear loci for linkage and confirmed that data were in Hardy-Weinberg equilibrium using GENE POP 3.4 (updated from Raymond and Rousset 1995). For 
the analysis of structure between and within groups, adult females from 14 harems (4-10 females per harem) were treated as 14 "populations". One harem was caught in Soberania and all others were from BCI. Pairwise $F_{\mathrm{ST}}$ (Weir and Cockerham 1984) from both the mtDNA and nuclear data sets was calculated among these female populations. Significance of the values was estimated using pairwise exact tests of population differentiation (Raymond and Rousset 1995; Goudet et al. 1996; 10,000 MC permutations with Arlequin 2.0 (Schneider et al. 2000). With the same software, we also calculated allele frequencies and estimated gene diversities (Nei 1987) after testing for genotypic equilibrium.

With Arlequin, we also calculated average pairwise $F_{\mathrm{ST}}$ among the 14 harems for both, the mitochondrial haplotypes and the microsatellite genotypes. To test for isolation by distance, we then correlated the values for each of the harems with geographical distance between their roosts in meters using a Mantel test in the application ISOLDE (implemented in GENEPOP (Raymond and Rousset 1995; 10,000 permutations)). If females settle closer to their natal roost than expected by chance, $F_{\mathrm{ST}}$ values should increase significantly with distance and vice versa. We also wanted to investigate whether males are more likely to settle close to their natal roosts after dispersal. $F_{\mathrm{ST}}$ values are a standard measure for pairwise comparisons but they cannot be calculated between single individuals. Consequently, we used pairwise relatedness (relatedness 5.0.8; updated from Queller and Goodnight 1989) to correlate the genotype and distance between roosts of the following 24 cavity owning males: $11 \mathrm{BCI}$-males with harems (in three harems the male had escaped at capture), eight solitary individuals from BCI owning a cavity without females, two males from peninsulas in the BCNM, and three from Soberania. If males settle close to their natal roost and hence to their father, we expected to find decreasing degrees of relatedness between males with increasing distance between roosts. Geographical distance between female harems ranged from 58 to $15,053 \mathrm{~m}$ (mean $=3,299 \mathrm{~m})$ and between males from 59 to $18,410 \mathrm{~m}($ mean $=3,782 \mathrm{~m})$.

Mark and recapture data indicate that individuals marked as juveniles are not recaptured with their parents when adult Dechmann et al. (2005). However, we captured many individuals only when they were already adult and the exact proportion of adult offspring that were not roosting with their parents was unknown. Thus, we conducted a paternity analysis according to the procedures established in Dechmann et al. (2005). We included all adults caught in roosts to quantify male and female natal dispersal by assigning individuals to their putative parents. We used the program Cervus 2.0 (Marshall et al. 1998), which predicts parents with the help of likelihood ratios obtained from the comparison of microsatellite data.
Simulations to calculate the significance of the parentage assignments were run separately for putative mothers (all adult females caught in termite nests) and fathers (all adult males caught in termite nests, including those from bachelor groups). The offspring file contained all animals from the parent files and as a result, every animal was tested against all others. The program was run with 10,000 permutations, a typing error of 0.01 , and a sampling rate of $50 \%$ (assessed by recapture rates). Confidence levels were set at $95 \%$. We only accepted parent-adult offspring pairs with a positive LOD (logarithm of likelihood ratio) and a maximum of one mismatch among loci (Marshall et al. 1998). In a second step, we excluded all assignments that provided impossible parent-offspring pairs, e.g., if an animal not yet born at the time of the sampling of the putative offspring was assigned as a putative parent.

Roost longevity and male tenure

The life span of excavated nests should limit male tenure because bats always desert termite nests that became inactive (e.g., the termites died or deserted the nest; Dechmann et al. 2004). Due to gaps between our field seasons, we checked nests at irregular intervals and consequently, we divided the entire study period into seven half-year fragments. For each half-year period, we determined whether known nests were active/excavated, active/ filled (as termites in active nests start to fill cavities after they are deserted by the bats; see also Kalko et al. 2006), or inactive. This allowed us to estimate the minimum life span $( \pm \mathrm{SD})$ of excavated nests. In most cases, we were not able to determine the absolute life span of nests because we do not know how long nests were active or used by the bats before we started our census. We only included those excavated termite nests in our analysis, which had been active upon discovery. We additionally quantified maximum time between recaptures of males at the same roost to estimate male tenure, which might differ from nest life span.

\section{Results}

Capture data and male-female ratio

We sampled a total of 298 adult L. silvicolum (128 males, 170 females), 272 on BCI and the rest of BCNM and 26 in Soberania. Individuals were caught between one and five times in mistnests and/or from roosts. We made a total of 61 capture attempts from 34 excavated nests. Three of the nests were located in Soberania and two on the peninsulas of the BCNM surrounding BCI. All others were on BCI. We caught significantly more adult females than males in roosts $\left(n_{\text {females }}=111, n_{\text {males }}=59 ; \chi^{2}=15.9, d f=1, p<0.0001\right)$ 
even when males caught in bachelor roosts were included (five groups containing only males; $n=20$ ). However, almost all groups containing females also contained a single adult male or at least one individual escaped at capture (Dechmann et al. 2005). In contrast, the number of males $(n=131)$ caught in nets did not differ significantly from the number of females $\left(n=127, \chi^{2}=0.06, d f=1, p=\right.$ $0.84)$. These recapture rates for males and females in nets confirmed that males were not easier to capture in nets than females. Several animals were caught in nets and roosts and they are included in both datasets. In the capture data, we also included roosting groups with fewer than four females, which were not used in the analyses of structure within and between groups (see below).

\section{DNA analysis}

The locus AJA123 was significantly linked with almost all other loci. We therefore excluded it from the analyses although we currently cannot explain this result. None of the other nine loci were linked and all 298 animals were analyzed with them. Mean number of alleles in those nine loci was $8-17(11.6 \pm 0.29)$ and observed heterozygosity was $0.76 \pm 0.07$. This did not differ from the expected value $\left(H_{\mathrm{e}}: 0.77 \pm 0.07\right)$ indicating the absence of null alleles. Sequencing 151 of the adults over $340 \mathrm{bp}$ at the d-loop resulted in 23 variable sites defining 25 haplotypes (GenBank accession numbers DQ160247-DQ160271, http://www.genbank.org).

\section{Structure within and between groups}

We compared the mitochondrial haplotypes and microsatellite genotypes of the 75 adult females from 14 groups. We only included groups where $75 \%$ or more of the animals and at least four females had been captured. Each group contained three to six haplotypes. Gene diversity within groups ranged from 0.8 to 1.0 for mtDNA and was close to 1.0 for each microsatellite as well as averaged over all loci in each group (summarized in Fig. 1). This means that the probability of two animals in the same group having the same mitochondrial or nuclear genotype was extremely low. This differs strongly from the pattern found in bat species with strong female philopatry, such as Myotis bechsteinii, where mtDNA diversity is significantly lower (Fig. 1). Pairwise differentiation between female groups of L. silvicolum was always nonsignificant for mitochondrial haplotypes (range of pairwise $F_{\mathrm{ST}}=-0.176$ to 0.166 ). For microsatellite genotypes, it was low and only significant between seven pairs of groups out of 105 pairs before Bonferroni corrections (significance threshold alpha $\leq 0.05$; range of $F_{\mathrm{ST}}=-0.073$ to 0.061 ; Table 1 ). We decided against sequential Bonferroni correction (Moran 2003),

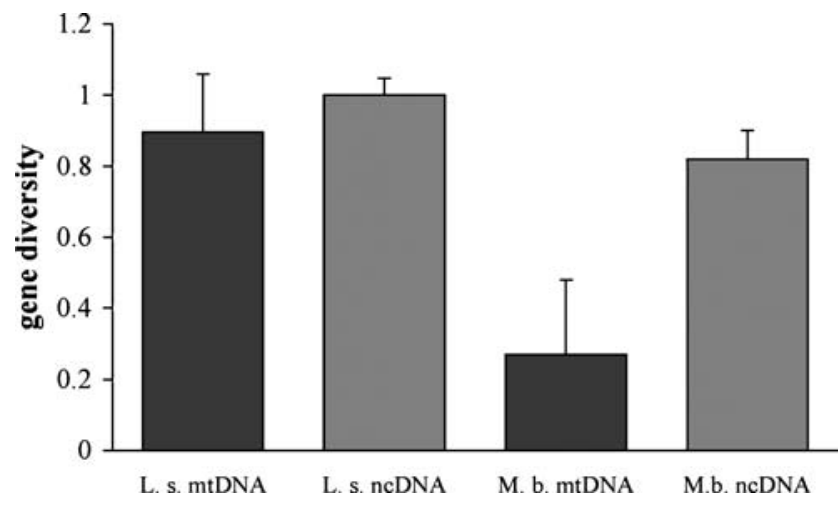

Fig. 1 Mitochondrial and nuclear genetic diversities of females from harems of Lophostoma silvicolum ( $n=14$ groups) and female groups of Myotis bechsteinii ( $n=20$ groups). Data for M. bechsteinii, which lives in closed female societies, while the males are solitary, are from Kerth et al. (2003)

which would have eliminated all significant relationships and results were interpreted without them.

In spite of the evidence for high gene flow between groups, there was a significant influence of distance between roosts on $F_{\mathrm{ST}}$-values for nuclear DNA (Mantel test; $\mathrm{rm}=-0.064 ; P_{\mathrm{r}}=0.01$; Fig. $\left.2 \mathrm{a}\right)$ but not for mitochondrial DNA $\left(\mathrm{rm}=-0.145 ; P_{\mathrm{r}}=0.12\right)$. We found no influence of distance on pairwise relatedness (range: -0.34 to 1 ; mean $=0.02)$ between the 24 males $\left(\mathrm{rm}=0.005 ; P_{\mathrm{r}}=0.359\right.$; Fig. 2b). Hence, isolation by distance was only evident for females and only for nuclear loci. To illustrate results, we plotted linear regression lines with SPSS 11.

We conducted the parentage analysis with all $159 \mathrm{BCI}$ adult individuals caught in roosts regardless of their relatedness with each other or whether they were known to have reproduced. Cervus found 79 possible parentoffspring pairs or close order relatives with one or no mismatches (107 females and 52 males). Only eight of these closely related pairs were caught at the same roost and only five pairs were found to be sharing the roost simultaneously. These data indicate that almost all offspring of both genders disperse from their natal roosts and, as adults, rarely return to roost with either parents or other close order relatives.

\section{Roost longevity and male tenure}

In $18(40 \%)$ of the 45 nests observed to estimate life span after excavation, the termite colony died during the study period. The other $27(60 \%)$ remained active until end of the study period. Not all roosts were known from the beginning of the study. However, those that became inactive had been observed for significantly longer than those that remained active (mean observation time (mean \pm SD) of nests that became inactive: $28 \pm 8.5$ months, nests active at the end of the observation period: $16.4 \pm 10.3$ months; $t=3.9, d f=43, p=$ $0.0003)$. We monitored roosts for a maximum of 
Table 1 Pairwise $F_{\mathrm{ST}}$-values (above diagonal) and $p$-values (below diagonal) between genotypes of the 14 groups of females

\begin{tabular}{llllllllllllllrr}
\hline & 1 & 2 & 3 & 4 & 5 & 6 & 7 & 8 & 9 & 10 & 11 & 12 & 13 & 14 \\
\hline 1 & $*$ & 0.025 & 0.015 & -0.058 & -0.030 & -0.061 & 0.002 & -0.024 & -0.007 & -0.021 & 0.010 & -0.003 & 0.051 & 0.036 \\
2 & 0.289 & $*$ & -0.023 & 0.007 & -0.010 & -0.008 & -0.002 & -0.033 & -0.016 & 0.013 & -0.004 & -0.009 & -0.020 & -0.015 \\
3 & 0.126 & 0.910 & $*$ & 0.012 & 0.006 & -0.007 & -0.008 & -0.014 & 0.004 & -0.006 & 0.005 & 0.002 & 0.012 & 0.051 \\
4 & 0.865 & 0.468 & 0.342 & $*$ & -0.030 & -0.022 & -0.017 & -0.032 & 0.021 & -0.028 & -0.025 & 0.012 & 0.017 & 0.022 \\
5 & 0.802 & 0.694 & 0.360 & 0.802 & $*$ & -0.041 & 0.003 & -0.046 & -0.039 & 0.001 & 0.009 & -0.016 & -0.010 & -0.011 \\
6 & 0.991 & 0.766 & 0.613 & 0.640 & 0.901 & $*$ & -0.022 & -0.032 & -0.044 & -0.019 & -0.013 & -0.030 & 0.046 & 0.024 \\
7 & 0.378 & 0.676 & 0.685 & 0.595 & 0.270 & 0.784 & $*$ & -0.074 & 0.024 & 0.023 & 0.004 & 0.007 & 0.037 & 0.059 \\
8 & 0.883 & 0.937 & 0.775 & 0.892 & 0.892 & 0.901 & 0.784 & $*$ & -0.007 & 0.013 & 0.016 & -0.023 & -0.006 & 0.011 \\
9 & 0.541 & 0.658 & 0.351 & 0.180 & 0.892 & 0.901 & 0.072 & 0.640 & $*$ & 0.017 & 0.033 & -0.011 & 0.037 & 0.019 \\
10 & 0.829 & 0.270 & 0.667 & 0.829 & 0.289 & 0.865 & 0.135 & 0.342 & 0.126 & $*$ & 0.001 & 0.000 & 0.011 & 0.040 \\
11 & 0.306 & 0.604 & 0.243 & 0.946 & 0.270 & 0.757 & 0.450 & 0.387 & $\mathbf{0 . 0 1 8}$ & 0.459 & $*$ & 0.019 & 0.039 & 0.062 \\
12 & 0.432 & 0.649 & 0.324 & 0.315 & 0.496 & 0.910 & 0.387 & 0.820 & 0.631 & 0.351 & 0.153 & $*$ & 0.009 & 0.033 \\
13 & 0.063 & 0.748 & 0.171 & 0.324 & 0.261 & $\mathbf{0 . 0 1 8}$ & $\mathbf{0 . 0 3 6}$ & 0.541 & $\mathbf{0 . 0 0 9}$ & 0.153 & $\mathbf{0 . 0 4 5}$ & 0.072 & $*$ & 0.021 \\
14 & 0.207 & 0.667 & $\mathbf{0 . 0 2 7}$ & 0.459 & 0.577 & 0.405 & 0.243 & 0.676 & 0.315 & 0.135 & $\mathbf{0 . 0 3 6}$ & 0.144 & 0.441 & $*$ &
\end{tabular}

*Significant values are bold. All values calculated with Arlequin. Standard deviation of $p$ values was \pm 0.07 or less (not shown).

42 months but none of them remained active for more than 30 months. The termites filled in seven roosts, but we do not know if this was a cause or consequence of the bats' deserting the roost. The bats later reexcavated two of those nests; in one case the new cavity was in a different part of the nest.

We recaptured six males up to three times in the same roost. Time between recaptures was between 5 days and 16 months. The two males we monitored in the same roost for the longest time period (12 and 16 months) disappeared shortly before the end of our last field season, although the cavity was still intact and used by females. We first caught one of these males in a termite nest, which had not contained a cavity 2 weeks previously. The male had a harem of three females with two pups, neither of which he had sired. Another male was caught in a new nest after the old termite colony had died. One female was caught with him in both nests and he had sired the pup she was with in the new roost. This is the second observation of a female following a male to a new termite nest (Dechmann et al. 2005). Although anecdotal, these data indicate that male tenure can last at least up to 36 months because females sometimes move roosts with a male, thus increasing male tenure beyond the life span of termite nest roosts. Finally, the disappearance of two males from active nests shows that male tenure length can be limited by other, unknown factors.

\section{Discussion}

Although sex-biased dispersal is common in animals, the causes are often disputed (Clobert et al. 2001). Differences in the dispersal behavior of the sexes is often not directly observable (Koenig et al. 1996) and there are still relatively few studies incorporating the use of genetic data (e.g., Favre et al. 1997; Seielstad et al. 1998; Banks et al. 2002; Bradley et al. 2004; Hammond et al. 2006). In mammals, dispersal is usually male biased (Greenwood 1980) and this also holds true for most bat species studied to date (Greenwood 1980; Burland et al. 1999; WorthingtonWilmer et al. 1999; Kerth et al. 2000; Castella et al. 2001; Petit et al. 2001; Kerth and Morf 2004). However, several studies on tropical species indicate that there may be cases where females also disperse (e.g., McCracken and Bradbury 1981; Storz et al. 2001). Our results suggest that in L. silvicolum, offspring of both sexes leave their natal group before first reproduction, resulting in no or very low local genetic population structure both for mitochondrial and nuclear DNA.

The equal numbers of females and males we caught in nets indicate that the highly female biased sex ratio observed within groups does not reflect differences between the actual numbers of adult males and females. Instead, it is a function of the social system. Single males living with females achieve high reproductive success while solitary males and bachelor males do not sire any pups (Dechmann et al. 2005). In contrast, most females reproduce at least once per year. In fact, about $70 \%$ of all females (including young adults born in the same year) were pregnant or lactating during the first reproductive season each year and $60 \%$ during the second (Dechmann et al. 2005).

Differences in operational sex ratio are a result of sexspecific dispersal strategies (Greenwood 1980; CluttonBrock 1989b). Several aspects of our results suggest that all offspring of $L$. silvicolum dispersed. In species such as $M$. bechsteinii from the temperate zone with male-mediated gene flow and closed female societies (Kerth et al. 2000), mitochondrial diversity is much lower than nuclear diversity (Fig. 1; Kerth et al. 2003; see also Burland and 

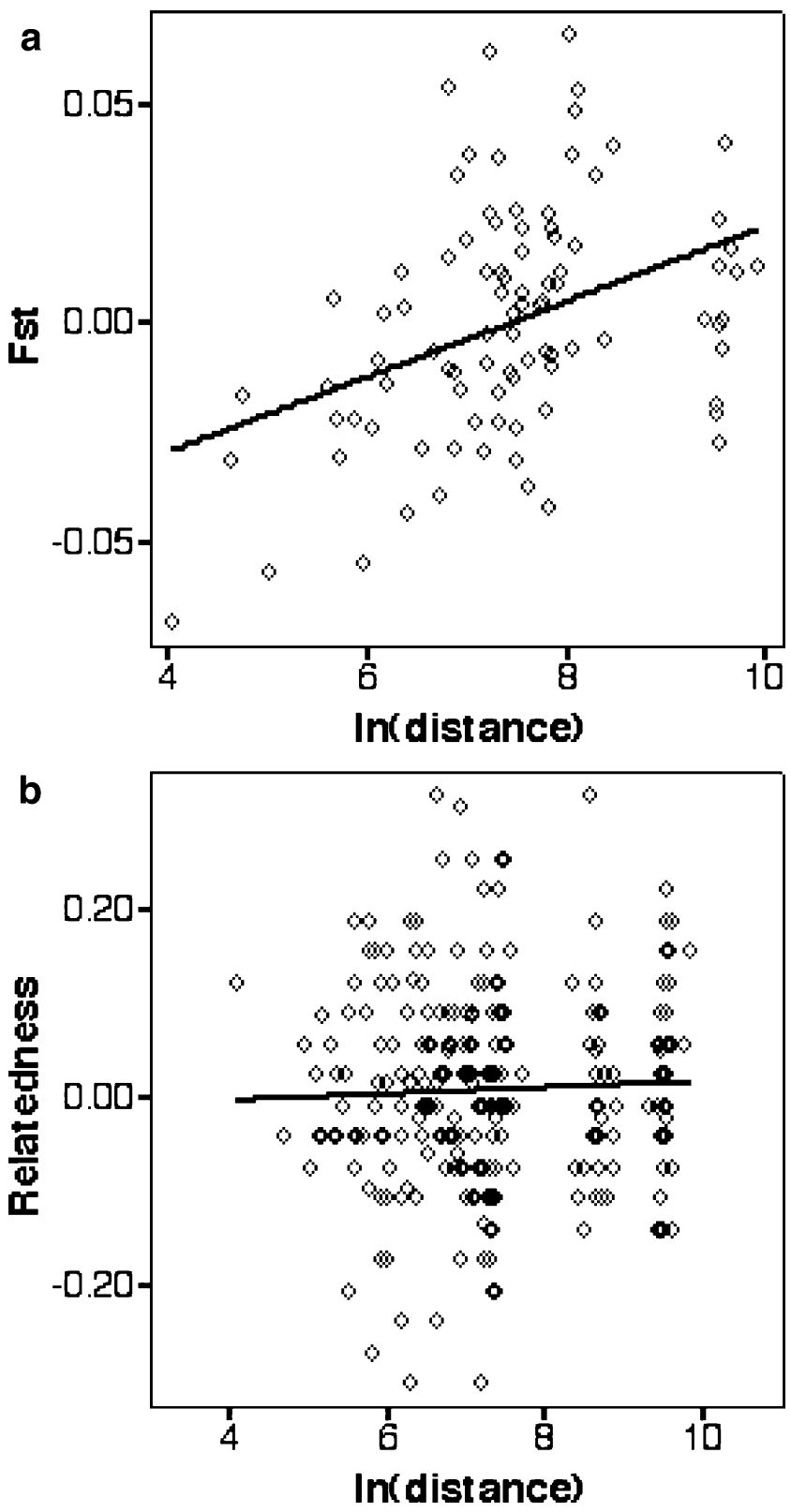

Fig. 2 a Pairwise $F_{\mathrm{ST}}$-values of female groups (excluding males), plotted against $\ln$ (distance) in meters between the groups' termite nests $(n=14)$. b Pairwise relatedness between nest-holding males plotted against $\ln$ (distance) in meters between the males' termite nests $(n=24)$

Worthington-Wilmer 2001: Plecotus auritus; Castella et al. 2001: Myotis myotis; Petit et al. 2001: Nyctalus noctula). In contrast, gene diversity of $L$. silvicolum in both mitochondrial and nuclear DNA was close to one, indicating that both sexes contribute to gene flow between harem groups. This concurs with the results of the paternity assignments, where we showed that only $5 \%$ or less of the adult offspring were present in their natal group compared to about $100 \%$ in temperate species like M. bechsteinii (Kerth et al. 2002b) or Rhinolophus ferrumequinum (Rossiter et al. 2000a,b).
Based on what is known about the natural history of L. silvicolum, we believe that limited access to mating partners and possibly aggression by the dominant male are the main reasons for male offspring dispersal in this, as in many other mammalian species (Greenwood 1980; Dobson 1982; Moore and Ali 1984). Food competition, which has been described as another common reason for dispersal (Greenwood 1980) is probably not very important in L. silvicolum because this species mainly feeds on large arthropods, an evenly distributed food source, which can not be defended (Belwood 1988). Moreover, occupied roosts of nonrelated males can be found at distances much less than the maximum flight distance from the roost to the foraging sites (20 vs $500 \mathrm{~m}$; Bockholdt 1998). This shows that males roost separately from each other although they probably could avoid scramble food competition even if they would share a roost (as the social bachelor males do). Males are also unlikely to compete for unexcavated termite nests because suitable termite nests do not seem to be limited on BCI (Kalko et al. 2006). In contrast, competition for reproduction in the small groups should be high and young males are likely to disperse to gain access to mating partners, possibly after being actively expelled by their father. But, we lack observations on this for $L$. silvicolum. Among other Neotropical bats from the same family, male expulsion does not always occur. For example, subordinate males, which are related to the dominant male queue for harem access in A. jamaicensis (Ortega et al. 2003), while in $D$. rotundus dominant males are aggressive towards younger males (Wilkinson 1985). Our data do not show how far male offspring disperse from their natal roost, but relatedness neither increases nor decreases with distance. Instead, dispersal distance appears to be largely random and is probably mainly influenced by the availability of a suitable territory and roost.

The lack of structuring in the mitochondrial DNA within and among female groups, as well as the paternity assignments provide evidence that females also disperse. Several reasons for female dispersal have been postulated (reviewed in Clutton-Brock 1989a). It is often assumed that dispersal costs are higher for females than for males, whereas the benefits are thought to be higher for males. We hypothesized that long male tenure and inbreeding avoidance might be a major reason for female offspring dispersal in $L$. silvicolum. Bats are generally long-lived, but females reach sexual maturity at an average age of only 8.5 months (Barclay et al. 2004). We do not know the average age at which female $L$. silvicolum reach sexual maturity, but our recapture data show that females can be as young as 6 months when first giving birth.

If male tenure were limited by the life span of the excavated termite nests, the formation of very long lasting roosting associations found in other bat species (Brooke 
1997; McCracken and Wilkinson 2000) would be impossible. Nevertheless, three lines of evidence indicate that male tenure in L. silvicolum is long enough to promote dispersal by young females to avoid inbreeding with their father. First, life span of roosts in termite nests can be 30 months and probably more. This is far more than female age at maturity. Second, females sometimes move to a new roost with a male, potentially extending male tenure beyond the life span of termite nests. Finally, female L. silvicolum that have been observed during more than one successive mating season often mated with the same male repeatedly (Dechmann et al. 2005). Thus, in species with female philopatry, daughters would still be in the roost of their father when they reach maturity. All this suggests that long male tenure is a likely cause for female dispersal. In contrast, the limited life span of roosts does not seem to cause female dispersal. In fact, groups of other species of bats change roosts together as frequently as every day (Kerth and König 1999; Sedgeley and O'Donnell 1999; Vonhof et al. 2004) and female offspring of such groups can be highly philopatric (Kerth et al. 2000).

There was no significant differentiation of either nuclear or mitochondrial DNA between harems when distance was not considered. But our test of isolation by distance indicated that nonetheless, dispersal by female L. silvicolum might not be completely random. There were only seven out of 105 pairs where we found a significant effect of distance on pairwise $F_{\mathrm{ST}}$-values between harems and only at the level of nuclear DNA. The absence of differentiation on the level of mtDNA may partially be due to the fact that only one marker was used, but a significant effect of distance can usually be shown even with only one mitochondrial marker (Castella et al. 2001; Kerth et al. 2002a; Clifford et al. 2004). The influence of distance may thus mainly be due to the fact that dispersing females profit from knowledge about neighboring roosts or hunting areas, and reduce dispersal costs by staying in the vicinity of their natal roost. When we captured bats at termite nests, females but not the male invariably deserted the roost at least temporarily. Females could be found in a new termite nest the following day and in up to three different roosts within a week (Dina Dechmann; unpublished data). This shows that females were aware of several roosts at a time and new groups of unrelated individuals accepted them immediately, which may reduce dispersal costs in L. silvicolum (see also Hammond et al. 2006), and allow young females to disperse only the minimal distance needed to avoid inbreeding with their father.

We postulate that female dispersal due to inbreeding avoidance may turn out to be fairly common in polygamous tropical bats. Known exceptions are species with cooperative behavior among female group members, such as $D$. rotundus (Wilkinson 1985). In such species, the benefits of living with familiar and/or related bats and thus the advantages of remaining in the natal group may be more important than the pressure to disperse. In case of D. rotundus, young females do indeed not always disperse in spite of the continued presence of their father in the group (Wilkinson 1985). However, this scenario does not apply to L. silviculum where no cooperative behavior between group members was observed (Dechmann et al. 2005; Lang et al. 2006).

In conclusion, the resource-defense polygyny of $L$. silvicolum in combination with relatively long male tenure probably provides a selective pressure for both male and female offspring to disperse from their natal group resulting in the observed lack of genetic population structure on a small geographical scale. Our results indicate that tropical bats, many of which have polygynous mating systems, may represent a large subgroup of mammals, where all-offspring dispersal occurs more regularly than in bats of the temperate zones. Thus, a polygynous mating system may lead to all-offspring dispersal more often than previously assumed in mammals.

Acknowledgements The Roche Research Foundation and the ZUNIV-Fonds zur Förderung des Akademischen Nachwuchses (FAN) financed Dina Dechmann during this study. The JuliusKlaus-Stiftung (Zürich) and the Brachet Foundation (Belgium) financed the genetic analyses, which were carried out with much help from J. Garbely. We want to thank the Smithsonian Tropical Research Institute (STRI) and the National Authority for the Environment (ANAM) for research permits and the staff of Barro Colorado Island, especially the game wardens for logistical support. The following people helped with fieldwork, development of equipment and/or with data analysis: A. Beck, M. Demir, S. Heucke, M. Kalka, R. Kays, J. Mandel, F. Neuhäuser-Wespy, K. Safi-Widmer, A. Schulz, M. Weinbeer, S. Wetterich, and especially K. Safi, A. Lang, S. Spehn, and C. Weise. We also thank M. Brigham, F. Mayer, A. McElligott, E. Petit, K. Safi, S. Spehn, and C. Voigt for valuable comments about the manuscript and B. König for her continuous support.

\section{References}

Banks SC, Skerratt LF, Taylor AC (2002) Female dispersal and relatedness structure in common wombats (Vombatus ursinus). J Zool 256:389-399

Barclay RMR, Ulmer J, MacKenzee CJA, Thompson MS, Olson L, McCool J, Cropey EE, Poll G (2004) Variation in the reproductive rate of bats. Can J Zool 82:688-693

Belwood JJ (1988) The influence of bat predation on calling behaviour in Neotropical forest katydids (Insecta: Orthoptera: Tettigoniidae). University of Florida, Gainesville

Bockholdt C (1998) Hangplatzwahl, Aktivitätsrhythmik und Aktionsraum der neotropischen Fledermaus Tonatia silvicola (D’Orbigny, 1836). Fakultät für Biologie. Universität Freiburg, Freiburg, pp 94

Bradley BJ, Doran-Sheehy DM, Lukas D, Boesch C, Vigilant L (2004) Dispersed male networks in western gorillas. Curr Biol 14:510-513

Brooke AP (1997) Social organization and foraging behaviour of the fishing bat, Noctilio leporinus (Chiroptera:Noctilionidae). Ethology 103:421-436 
Burland TM, Worthington-Wilmer JW (2001) Seeing in the dark: molecular approaches to the study of bat populations. Biol Rev 76:389-409

Burland TM, Barratt EM, Beaumont MA, Racey PA (1999) Population genetic structure and gene flow in a gleaning bat, Plecotus auritus. Proc R Soc Lond B 266:975-980

Burland TM, Barratt EM, Nichols RA, Racey PA (2001) Mating patterns, relatedness and the basis of natal philopatry in the brown long-eared bat, Plecotus auritus. Mol Ecol 10:1309-1321

Castella V, Ruedi M, Excoffier L (2001) Contrasted patterns of mitochondrial and nuclear structure among nursery colonies of the bat Myotis myotis. J Evol Biol 14:708-720

Clarke AL, Saether B-E, Roskraft E (1997) Sex biases in avain dispersal: a reappraisal. Oikos 79:429-438

Clifford SL, Anthony NM, Bawe-Johnson M, Abernethy KA, Tutin CEG, White LJT, Bermejo M, Goldsmith ML, McFarland K, Jeffery KJ, Bruford MW, Wickings EJ (2004) Mitochondrial DNA phylogeography of western lowland gorillas (Gorilla gorilla gorilla). Mol Ecol 13:1551-1565

Clobert J, Danchin E, Dhondt AA, Nichols JD (2001) Dispersal. Oxford University Press, Oxford, UK

Clutton-Brock TH (1989a) Female transfer and inbreeding avoidance in social mammals. Nature 337:70-72

Clutton-Brock TH (1989b) Mammalian mating systems. Proc R Soc Lond B 236:339-372

Dechmann DKN, Garbely E, Kerth G, Garner TWJ (2002) Highly polymorphic microsatellites for the study of the round-eared bat, Tonatia silvicola (d'Orbigny). Conservation Genetics 3:455458

Dechmann DKN, Kalko EKV, Kerth G (2004) Ecology of an exceptional roost: energetic benefits could explain why the bat Lophostoma silvicolum roosts in active termite nests. Evol Ecol Res 6:1037-1050

Dechmann DKN, Kalko EKV, König B, Kerth G (2005) Mating system of a Neotropical roost making bat: the white-throated, round-eared bat, Lophostoma silvicolum (Chiroptera: Phyllostomidae). Behav Ecol Sociobiol 58:316-325

Dobson FS (1982) Competition for mates and predominant juvenile male dispersal in mammals. Anim Behav 30:1183-1192

Favre L, Balloux F, Goudet J, Perrin N (1997) Female-biased dispersal in the monogamous mammal Crocidura russula: Evidence from field data and microsatellite patterns. Proc R Soc Lond B Biol Sci 264:127-132

Goudet J, Raymond M, de Meeüs T, Rousset F (1996) Testing differentiation in diploid populations. Genetics 144:1933-1940

Greenwood PJ (1980) Mating systems, philopatry and dispersal in birds and mammals. Anim Behav 28:1140-1162

Hammond RL, Lawson Handley LJ, Wineey BJ, Bruford MW, Perrin N (2006) Genetic evidence for female-biased dispersal and gene flow in a polygynous primate. Proc R Soc B 273:479-484

Heckel G, Von Helversen O (2003) Genetic mating system and the significance of harem associations in the bat Saccopteryx bilineata. Mol Ecol 12:219-227

Heckel G, Voigt CC, Mayer F, Von Helversen O (1999) Extraharem paternity in the white-lined bat Saccopteryx bilineata (Emballonuridae). Behaviour 136:1173-1185

Kalko EKV, Handley CO, Handley D (1996) Organization, diversity, and long-term dynamics of a Neotropical bat community. In: Cody ML, Smallwood JA (eds) Long-term studies of vertebrate communities. Academic Press, San Diego, pp 503-553

Kalko EKV, Friemel D, Handley CO, Schnitzler HU (1999) Roosting and foraging behavior of two Neotropical gleaning bats, Tonatia silvicola and Trachops cirrhosus (Phyllostomidae). Biotropica 31:344-353

Kalko EKV, Ueberschaer K, Dechmann DKN (2006) Roost structure, modification, and availability in the white-throated, round-eared bat, Lophostoma silvicolum (Phyllostomidae) living in active termite nests. Biotropica 38:1-7

Kerth G, König B (1996) Transponder and an infrared-videocamera as methods used in a field study on the social behaviour of Bechstein's Bat (Myotis bechsteinii). Myotis 34:27-34

Kerth G, König B (1999) Fission, fusion and nonrandom associations in female Bechstein's bats (Myotis bechsteinii). Behaviour 136:1187-1202

Kerth G, Morf L (2004) Behavioural and genetic data suggest that Bechstein's bats predominantly mate outside the breeding habitat. Ethology 110:987-999

Kerth G, Mayer F, König B (2000) Mitochondrial DNA (mtDNA) reveals that female Bechstein's bats live in closed societies. Mol Ecol 9:793-800

Kerth G, Mayer F, Petit E (2002a) Extreme sex-biased dispersal in the communally breeding, nonmigratory Bechstein's bat (Myotis bechsteinii). Mol Ecol 11:1491-1498

Kerth G, Safi K, Konig B (2002b) Mean colony relatedness is a poor predictor of colony structure and female philopatry in the communally breeding Bechstein's bat (Myotis bechsteinii). Behav Ecol Sociobiol 52:203-210

Kerth G, Kiefer A, Trappmann C, Weishaar M (2003) High gene diversity at swarming sites suggest hot spots for gene flow in the endangered Bechstein's bat. Conservation Genetics 4:491-499

Koenig WD, Van Vuren D, Hooge PN (1996) Detectability, philopatry, and the distribution of dispersal distances in vertebrates. Trends Ecol Evol 11:514-517

Lang AB, Kalko EKV, Römer H, Bockholdt C, Dechmann DKN (2006) Activity levels of bats and katydids in relation to the lunar cycle. Oecologia 146:659-666

Marshall TC, Slate J, Kruuk LEB, Pemberton JM (1998) Statistical confidence for likelihood-based paternity inference in natural populations. Mol Ecol 7:639-655

McCracken GF, Bradbury JW (1981) Social organization and kinship in the polygynous bat Phyllostomus hastatus. Behav Ecol Sociobiol 8:11-34

McCracken GF, Wilkinson GS (2000) Bat mating systems. In: Crichton EG, Krutzsch PH (eds) Reproductive biology of bats. Academic Press, London, pp 321-357

Moore J, Ali R (1984) Are dispersal and inbreeding avoidance related. Anim Behav 32:94-112

Moran MD (2003) Arguments for rejecting the sequential Bonferroni in ecological studies. Oikos 100:403-405

Müllenbach R, Lagoda PJL, Welter C (1989) An efficient salt chloroform extraction method of DNA from blood and tissues. Trends Genet 5:391

Nei M (1987) Molecular evolutionary genetics. Columbia University Press, New York

Ortega J, Maldonado JE, Arita HT, Wilkinson GS, Fleischer RC (2002) Characterization of microsatellite loci in the Jamaican fruit-eating bat Artibeus jamaicensis and cross-species amplification. Mol Ecol Notes 2:462-464

Ortega J, Maldonado JE, Wilkinson GS, Arita HT, Fleischer RC (2003) Male dominance, paternity, and relatedness in the Jamaican fruiteating bat (Artibeus jamaicensis). Mol Ecol 12:2409-2415

Perrin N, Mazalov V (1999) Dispersal and inbreeding avoidance. Am Nat 154:282-292

Petit E, Balloux F, Goudet J (2001) Sex-biased dispersal in a migratory bat: a characterization using sex-specific demographic parameters. Evolution 55:635-640

Queller DC, Goodnight KF (1989) Estimating relatedness using genetic-markers. Evolution 43:258-275

Raymond M, Rousset F (1995) An exact test for population differentiation. Evolution 49:1280-1283

Reid FA (1997) A field guide to the mammals of Central America and Southeast Mexico. Oxford University Press, New York, Oxford 
Rossiter SJ, Jones G, Ransome RD, Barratt EM (2000a) Genetic variation and population structure in the endangered greater horseshoe bat Rhinolophus ferrumequinum. Mol Ecol 9:1131-1135

Rossiter SJ, Jones G, Ransome RD, Barratt EM (2000b) Parentage, reproductive success and breeding behaviour in the greater horseshoe bat (Rhinolophus ferrumequinum). Proc R Soc Lond, B Biol Sci 267:545-551

Rossiter SJ, Jones G, Ransome RD, Barratt EM (2002) Relatedness structure and kin-biased foraging in the greater horseshoe bat (Rhinolophus ferrumequinum). Behav Ecol Sociobiol 51:510-518

Rossiter SJ, Ransome RD, Faulkes CG, Le Comber SC, Jones G (2005) Mate fidelity and intra-lineage polygyny in greater horseshoe bats. Nature 437:408-411

Ruckstuhl KE, Neuhaus P (2000) Sexual segregation in ungulates: a new approach. Behaviour 137:361-377

Schneider S, Roessli D, Escoffier L (2000) Arlequin ver. 2.000: a software for population genetics data analysis. Genetics and Biometry Laboratory, University of Geneva, Switzerland

Sedgeley JA, O'Donnell CFJ (1999) Roost selection by the long-tailed bat, Chalinolobus tuberculatus, in temperate New Zealand rainforest and its implications for the conservation of bats in managed forests. Biol Conserv 88:261-276

Seielstad MT, Minch E, Cavalli-Sforza LL (1998) Genetic evidence for a higher female migration rate in humans. Nat Genet 20:278-280

Shuster SM, Wade MJ (2003) Mating systems and strategies. Princeton Press, Princeton
Storz JF, Bhat HR, Kunz TH (2000) Social structure of a polygynous tent-making bat, Cynopterus sphinx (Megachiroptera). J Zool 251:151-165

Storz JF, Bhat HR, Kunz TH (2001) Genetic consequences of polygyny and social structure in an Indian fruit bat, Cynopterus sphinx. I. Inbreeding, outbreeding, and population subdivision. Evolution 55:1215-1223

Vonhof MJ, Whitehead H, Fenton MB (2004) Analysis of Spix's discwinged bat association patterns and roosting home ranges reveal a novel social structure among bats. Anim Behav 68:507-521

Weir BS, Cockerham CC (1984) Estimating F-statistics for the analysis of population structure. Evolution 38:1358-1370

Wilkinson GS (1985) The social-organization of the common vampire bat 2. Mating system, genetic-structure, and relatedness. Behav Ecol Sociobiol 17:123-134

Wilkinson GS, Chapman AM (1991) Length and sequence variation in evening bat D-Loop MtDNA. Genetics 128:607-617

Wilkinson GS, Mayer F, Kerth G, Petri B (1997) Evolution of repeated sequence arrays in the D.loop region of bat mitochondrial DNA. Genetics 146:1035-1048

Williams DA, Rabenold KN (2005) Male-biased dispersal, female philopatry, and routes to fitness in a social corvid. J Anim Ecol 74:150-159

Worthington-Wilmer J, Hall L, Barratt E, Moritz C (1999) Genetic structure and male-mediated gene flow in the ghost bat (Macroderma gigas). Evolution 53:1582-1591 